\title{
Development of a Specific Polymerase Chain Reaction-Based Assay for the Identification of Fusarium oxysporum f. sp. ciceris and Its Pathogenic Races 0, 1A, 5, and 6
}

\author{
María del Mar Jiménez-Gasco and Rafael M. Jiménez-Díaz
}

First author: Departamento de Protección de Cultivos, Instituto de Agricultura Sostenible (IAS), Consejo Superior de Investigaciones Científicas (CSIC), Apartado 4084, 14080 Córdoba, Spain; and second author: Departamento de Protección de Cultivos, IAS-CSIC, and Escuela Técnica Superior de Ingenieros Agrónomos y de Montes, Universidad de Córdoba, Apartado 3048, 14080 Córdoba, Spain. Accepted for publication 13 September 2002.

\begin{abstract}
Jiménez-Gasco, M. M., and Jiménez-Díaz, R. M. 2003. Development of a specific polymerase chain reaction-based assay for the identification of Fusarium oxysporum f. sp. ciceris and its pathogenic races $0,1 \mathrm{~A}, 5$, and 6. Phytopathology 93:200-209.

Specific primers and polymerase chain reaction (PCR) assays that identify Fusarium oxysporum f. sp. ciceris and each of the F. oxysporum f. sp. ciceris pathogenic races $0,1 \mathrm{~A}, 5$, and 6 were developed. $F$. oxysporum f. sp. ciceris- and race-specific random amplified polymorphic DNA (RAPD) markers identified in a previous study were cloned and sequenced, and sequence characterized amplified region (SCAR) primers for specific PCR were developed. Each cloned RAPD marker was characterized by Southern hybridization analysis of EcoRI-digested genomic DNA of a subset of $F$. oxysporum f. sp. ciceris and nonpathogenic $F$. oxysporum isolates. All except two cloned RAPD markers consisted of DNA sequences that were found highly repetitive in the genome of all $F$. oxysporum f. sp. ciceris races. $F$. oxysporum f. sp. ciceris isolates representing eight reported races from a wide geographic range, nonpathogenic $F$. oxysporum isolates, isolates of $F$. oxysporum $\mathrm{f}$.
\end{abstract}

ABSTRACT spp. lycopersici, melonis, niveum, phaseoli, and pisi, and isolates of 47 different Fusarium spp. were tested using the SCAR markers developed. The specific primer pairs amplified a single 1,503-bp product from all $F$. oxysporum f. sp. ciceris isolates; and single $900-$ and 1,000-bp products were selectively amplified from race 0 and race 6 isolates, respectively. The specificity of these amplifications was confirmed by hybridization analysis of the PCR products. A race 5-specific identification assay was developed using a touchdown-PCR procedure. A joint use of race 0 - and race 6-specific SCAR primers in a single-PCR reaction together with a PCR assay using the race 6-specific primer pair correctly identified race 1A isolates for which no RAPD marker had been found previously. All the PCR assays described herein detected up to $0.1 \mathrm{ng}$ of fungal genomic DNA. The specific SCAR primers and PCR assays developed in this study clearly identify and differentiate isolates of $F$. oxysporum $\mathrm{f}$. sp. ciceris and of each of its pathogenic races $0,1 \mathrm{~A}, 5$, and 6 .

Additional keywords: Cicer arietinum, diagnostics, DNA hybridizations, DNA markers, Fusarium wilt of chickpea, repetitive DNA.
Accurate and rapid identification of pathogens is necessary for appropriate management of plant diseases. In particular, phenotypic and genetic characterization of the pathogenic variants of the plant pathogens prevalent in an area is required for efficient disease management. Fusarium oxysporum Schlechtend.:Fr. is an anamorphic soilborne fungus that includes both nonpathogenic and plant-pathogenic isolates. Pathogenic forms of this fungus cause vascular and cortical rot diseases in many agricultural crops, and have been classified into formae speciales based on their host specificity (26). Also, variation in virulence among host cultivars can be found within isolates of a forma specialis, leading to the designation of pathotypes and pathogenic races (26).

F. oxysporum f. sp. ciceris (Padwick) Matuo \& K. Sato, the agent of Fusarium wilt of chickpea (Cicer arietinum L.), exhibits great diversity. Two pathotypes, yellowing and wilting, have been differentiated by the disease syndrome induced in the plant in pathogenicity tests (34). The yellowing pathotype induces progressive foliar yellowing with vascular discoloration, followed by plant death within 40 days of inoculation. The wilting pathotype induces severe chlorosis and flaccidity, vascular discoloration, and plant death within 20 days after inoculation. In addition to variation in symptom type, there are eight races of $F$. oxysporum f. sp.

Corresponding author: R. M. Jiménez-Díaz; E-mail address: agljidir@uco.es

Publication no. P-2002-1213-01R

(C) 2003 The American Phytopathological Society ciceris (races $0,1 \mathrm{~A}, 1 \mathrm{~B} / \mathrm{C}, 2,3,4,5$, and 6 ), which are identified by reactions on a set of differential chickpea cultivars $(12,15)$. Races 0 and $1 \mathrm{~B} / \mathrm{C}$ induce the yellowing syndrome (yellowing pathotype), whereas races $1 \mathrm{~A}, 2,3,4,5$, and 6 induce the wilting syndrome (wilting pathotype) (15). The eight races have distinct geographic distributions. Races 2, 3, and 4 have been reported only in India (12), whereas races $0,1 \mathrm{~B} / \mathrm{C}, 5$, and 6 are found mainly in the Mediterranean region and in the United States (California) $(11,15,17)$. Race 1A has been reported in India (12), California, and the Mediterranean region $(15,17)$.

Fusarium wilt of chickpea is managed primarily by the use of resistant cultivars (14). This makes the identification of pathogenic races of $F$. oxysporum $\mathrm{f}$. sp. ciceris in a given area important for disease resistance breeding and for the efficient use of resistant cultivars. In the absence of alternative methods, $F$. oxysporum isolates from chickpea are characterized into $F$. oxysporum f. sp. ciceris and further into pathogenic races. Determination of races in this pathogen is conceptually simple but costly in time (50 to 60 days), facilities, and resources (15,34). Furthermore, nonpathogenic $F$. oxysporum isolates infecting the chickpea root cortex may be identified as $F$. oxysporum f. sp. ciceris due to the variability inherent to biological pathotyping $(17,19)$. Therefore, new methods for the rapid, consistent, reliable, and reproducible identification of the pathogen and its pathogenic races are needed.

Polymerase chain reaction (PCR) has been widely and successfully employed for the identification of important plant-pathogenic 
fungi $(13,23)$. In many cases, primers for these uses were based on DNA sequence polymorphisms existing within highly conserved regions of the nuclear ribosomal DNA, such as the internal transcribed spacer or the intergenic spacer region (35). Although this strategy proved successful for species identification (3), the above regions do not normally reveal sufficient polymorphism for distinguishing subspecific groups such as formae speciales or pathogenic races. An alternative strategy in the development of markers for infraspecific taxa is based on the isolation and sequencing of distinct fragments of random amplified polymorphic DNA (RAPD), and the use of these sequences to design PCR primers that specifically amplify selected markers. This approach of using sequence characterized amplified regions (SCARs) was first applied by Paran and Michelmore (29), and since then has been very effective for the intraspecific identification of a diversity of plant pathogens $(20,24)$.

In a previous study, we analyzed a worldwide collection of $F$. oxysporum $\mathrm{f}$. $\mathrm{sp}$. ciceris isolates representative of all pathogen races, as well as nonpathogenic $F$. oxysporum isolates (17). Pathogenic isolates were unambiguously typed as $F$. oxysporum $\mathrm{f}$. sp. ciceris and pathogenic races $0,1 \mathrm{~B} / \mathrm{C}, 5$, and 6 by distinct RAPD markers. The applicability of those markers for diagnostic purposes was confirmed by biological and molecular "blind trials" and found reproducible in repeated amplification experiments (17). However, the reliability of RAPD markers might be influenced by the source and procedure used for DNA isolation, the occurrence of contaminants, the amplification of different DNA sequences of the same size, the thermocycler, reaction conditions, and other factors. This limits the use of the RAPD markers for general diagnostics among many laboratories. To overcome these difficulties, there is a need to develop improved molecular assays and markers for the identification of the pathogen and its pathogenic races.

The aim of the present study was to develop a PCR assay that could selectively discriminate isolates of $F$. oxysporum $\mathrm{f}$. sp. ciceris from nonpathogenic $F$. oxysporum from chickpea, other $F$. oxysporum formae speciales and Fusarium spp., and identify the races of the pathogen that are prevalent in the Mediterranean region. Our approach was based in that $F$. oxysporum f. sp. ciceris is a strictly asexually reproducing, highly clonal fungus $(16,30)$ in which genetic recombination does not occur and for which genetic markers can be used to identify races. For our purpose, we used SCARs to generate specific PCR primers based on informative RAPD markers and optimized conditions for assays (17). This process required the cloning, sequencing, and characterization of the RAPD markers of the races.

\section{MATERIALS AND METHODS}

Fungal isolates. A large, systematic collection of fungal isolates was used in this study, consisting of $76 \mathrm{~F}$. oxysporum f. sp. ciceris isolates representative of the eight described races and from a wide geographic distribution of the pathogen, 20 chickpea isolates of $F$. oxysporum from roots of healthy plants and nonpathogenic to chickpea, 15 isolates from five different $F$. oxysporum formae speciales, and 58 isolates of 47 different Fusarium spp. (Table 1). The isolates of $F$. oxysporum f. sp. ciceris races were characterized in previous studies (15, 17,19).

All 96 F. oxysporum isolates from chickpea (including pathogenic and nonpathogenic ones) and five isolates of other $F$. oxysporum formae speciales were from the culture collection of Departamento de Protección de Cultivos, Instituto de Agricultura Sostenible, CSIC, Córdoba, Spain. An isolate of $F$. oxysporum $\mathrm{f}$. sp. lycopersici was a gift from D. Fravel, U.S. Department of Agriculture-Agricultural Research Service (USDA-ARS), Beltsville, $\mathrm{MD}$, and eight $F$. oxysporum $\mathrm{f}$. sp. pisi isolates were provided by W. Boge, USDA-ARS, Prosser, WA. Isolates of other
Fusarium spp. were obtained from J. F. Leslie, Department of Plant Pathology, Kansas University, Manhattan. Monoconidial cultures of isolates were stored in sterile soil in test tubes at $4^{\circ} \mathrm{C}$ (26). Active cultures of the isolates were subsequently obtained by placing small aliquots of the soil culture onto a plate of fresh potato dextrose agar (PDA) (250 g of unpeeled potatoes, $20 \mathrm{~g}$ of agar, and $20 \mathrm{~g}$ of glucose per liter of distilled water) and incubating for 4 days at $25^{\circ} \mathrm{C}$ and a 12 -h photoperiod of fluorescent and near-UV light at $36 \mu \mathrm{E} \mathrm{m}^{-2} \mathrm{~s}^{-1}$. Mycelia for DNA extraction were produced by the following methods. (i) For large-scale production of mycelium, $1 \mathrm{ml}$ of conidial suspension $\left(5 \times 10^{6}\right.$ conidia per $\mathrm{ml}$ ) was transferred to 250 -ml flasks containing $100 \mathrm{ml}$ of potato dextrose broth (250 g of unpeeled potatoes and $20 \mathrm{~g}$ of glucose per liter of distilled water). Cultures were incubated on an orbital shaker at $125 \mathrm{rpm}, 25^{\circ} \mathrm{C}$, and $12 \mathrm{~h}$ of light for 4 days. Mycelia were harvested by filtration through sterile cloth, washed with sterile water, lyophilized, and stored at $-20^{\circ} \mathrm{C}$. (ii) For smallscale production of mycelium, a small piece from an active fungal culture on PDA was placed onto a sterile cellophane film layered over a PDA plate and incubated at $25^{\circ} \mathrm{C}$ and $12 \mathrm{~h}$ of light for 4 to 6 days. Mycelia were harvested from the cellophane surface, lyophilized, and stored at $-20^{\circ} \mathrm{C}$.

DNA extraction. Genomic DNA of the fungal isolates was purified from $50 \mathrm{mg}$ of lyophilized ground mycelia as described by Raeder and Broda (31), with slight modifications. Ground mycelium was suspended in an extraction buffer $(200 \mathrm{mM}$ Tris$\mathrm{HCl}$ [pH 8.5], $25 \mathrm{mM} \mathrm{NaCl}, 25 \mathrm{mM}$ EDTA, and $0.5 \%$ sodium dodecyl sulfate). The mixture was homogenized with equilibrated phenol/chloroform/isoamyl alcohol (25:24:1), and centrifuged for $1 \mathrm{~h}$ at $12,000 \times g\left(4^{\circ} \mathrm{C}\right)$. The supernatant was treated with RNAase and extracted with chloroform/isoamyl alcohol (24:1), followed by centrifugation $\left(15 \mathrm{~min}\right.$ at $12,000 \times g$ and $\left.4^{\circ} \mathrm{C}\right)$. DNA was precipitated by adding cold isopropanol, resuspended in sterile water, and stored at $-20^{\circ} \mathrm{C}$. Aliquots of the DNA samples were analyzed on $0.7 \%$ agarose gels in $1 \times$ Tris-acetate-EDTA (TAE) buffer to estimate the concentration and quality of the extracted DNA. For PCR reactions, samples were diluted to a final concentration of 25 to $50 \mathrm{ng} / \mu \mathrm{l}$ in sterile water.

Cloning of RAPD fragments. The following RAPD markers of $F$. oxysporum f. sp. ciceris and of its pathogenic races $0,1 \mathrm{~B} / \mathrm{C}$, 5, and 6 (17) were cloned: F. oxysporum f. sp. ciceris, $1.5 \mathrm{~kb}$ (OPF-12, 5'-ACGGTACCAG-3'); race 0, $0.39 \mathrm{~kb}(\mathrm{OPF}-12)$ and $0.9 \mathrm{~kb}$ (OPI-09, 5' -TGGAGAGCAG-3'); race 1B/C, $0.53 \mathrm{~kb}(\mathrm{OPI}-$ $09)$ and $1.1 \mathrm{~kb}$ (OPF-10, 5'-GGAAGCTTGG-3'); race 5, $0.9 \mathrm{~kb}$ (OPF-10); and race 6, 1.0 and $1.4 \mathrm{~kb}$ (OPI-09) (Operon Technology, Alameda, CA). RAPD reactions were carried out as described previously (17). RAPD products were separated by electrophoresis in $1.5 \%$ agarose gels in $1 \times$ TAE buffer, stained with ethidium bromide, and visualized under UV light. The $0.1-\mathrm{kb}$ DNA ladder XIV size marker was used for electrophoresis (Roche Diagnostics, Mannheim, Germany). The RAPD markers of $F$. oxysporum f. sp. ciceris or its pathogenic races were excised from the agarose gel, and DNA was purified using the Qiaex gel extraction kit (Qiagen, Hilden, Germany). The purified RAPD products were cloned into the vectors pGem-T (Promega, Madison, WI) or pCR2.1 TOPO (TOPO TA, Invitrogen, Groningen, Netherlands) according to the manufacturer's instructions and used to transform competent Escherichia coli cells. For each cloned RAPD marker, plasmid DNA was released from 30 to 50 transformed E. coli colonies by the alkaline lysis method (33). A RAPD marker may comprise DNA fragments of the same size but differing in sequence; therefore, we aimed to ensure that DNA inserts carried by selected bacterial clones corresponded to the putative correct RAPD marker. Therefore, insert DNAs were digested with ApaI, BamHI, EcoRI, PstI, SacI, and XbaI endonucleases (Pharmacia LKB, Upsala, Sweden) and the restriction analyses identified a number of different DNA sequences. Thereafter, we hybridized blotted RAPD patterns associated to $F$. 
oxysporum $\mathrm{f}$. $\mathrm{sp}$. ciceris and its pathogenic races $0,1 \mathrm{~B} / \mathrm{C}, 5$, and 6 using each DNA insert as a probe to verify that the insert hybridized only to the race from which the SCAR was developed.

Hybridization assays. Three types of hybridization assays were carried out in this study using each of the cloned RAPD markers as a probe: (i) hybridization of blotted RAPD patterns, (ii) hybridization of fungal genomic DNA digested with the restriction enzyme EcoRI (Southern blot), and (iii) hybridization of blotted specific PCR products. For hybridization analyses of either RAPD patterns or specific PCR products, amplification products $(25 \mu \mathrm{l})$ were separated in $1.5 \%$ agarose gels and transferred onto nylon Zeta-Probe blotting membranes (Bio-Rad Laboratory, S.A., Madrid, Spain) by capillarity in alkaline conditions (33). Cloned RAPD markers used as probes were labeled using digoxigenin-3-O-methylcarbonyl-amino-caproyl-5(3-aminoallyl)-uridine-5' -triphosphate (DIG-11-dUTP) by random-

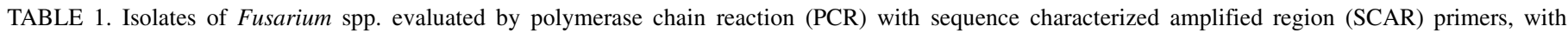
reference number, geographic origin, and race classification

\begin{tabular}{|c|c|c|}
\hline Isolate reference $^{a}$ & Geographic origin $^{\mathrm{b}}$ & Isolate reference $^{\mathrm{a}}$ \\
\hline Fusarium oxysporum f. sp. ciceris & & F. acuminatum 11442 \\
\hline Race 0 & & F. acutatum 10769 \\
\hline Foc-7802, $-7952,-8207,-82108,-82113,-8503,-8733,-8912,-9018$ & Spain & F. armeniacum 11623 \\
\hline PV1, -9018 JG62, -9032, -90111, -91100, -91015, -91108, -91114 & & F. andiyazi 4647 \\
\hline Foc-9601, -9603, -9604, -9605, -9606, -T3 & Tunisia & F. anthophilum 11560 \\
\hline Foc-cc $21 \mathrm{C},-\mathrm{cc} 62 \mathrm{R},-\mathrm{cc} 63 \mathrm{~K}$ & Israel & F. avenaceum 11440 \\
\hline Foc-L96-5, -L96-6, -L96-7, -L96-9, -L96-10, -L96-11 & Lebanon & F. babinda 11478 \\
\hline Foc-Sy 96-14-1, -Sy 96-18-3, -Sy 96-19-1 & Syria & F. begoniae 10767 \\
\hline Foc-T 96-1-3 & Turkey & F. brevicatenulatum 10756 \\
\hline Race $1 \mathrm{~B} / \mathrm{C}$ & & F. bulbicola 10759 \\
\hline Foc-USA 3-1JG62, -1987-W17 & United States & F. chlamydosporum 11397 \\
\hline Foc-9602 & Tunisia & F. circinatum $10766, \mathrm{H}-10847$ \\
\hline Foc-Sy 96-10-1 & Syria & F. circinatum $\mathrm{H}-10850$ \\
\hline Foc-T 96-1-1, -Т 96-1-2, T -96-2-1, -Т 96-2-2 & Turkey & F. compactum 11624 \\
\hline Foc-cc22D & Israel & F. concentricum 10765 \\
\hline Race $1 \mathrm{~A}$ & & F. crookwellense 11451 \\
\hline Foc-7989 & India & F. culmorum 11427 \\
\hline Foc-9168 & Morocco & F. decemcellulare 11411 \\
\hline Foc- 8272 & Spain & F. denticulatum 10763 \\
\hline Race 2 & & F. dimerum 11425 \\
\hline Foc-8605, -1992 R2N & India & F. equiseti 11439 \\
\hline Race 3 & & F. globosum 11554 \\
\hline Foc-8606, $-1992 \mathrm{R} 3 \mathrm{~N}$ & India & F. guttiforme 10764 \\
\hline Race 4 & & F. lactis 10757 \\
\hline Foc- $8607,-1992 \mathrm{R} 4 \mathrm{~N}$ & India & F. lateritium 11403 \\
\hline Race 5 & & F. longipes 11428 \\
\hline Foc-8012, -8257, -8408, -8508, -9035, -9094 PV1, & Spain & F. nelsonii 11564 \\
\hline-9094 JG62 & & F. nisikadoi 10758 \\
\hline Foc-USA1-1JG62, -USA W6-1, -USA14201 & United States & F. nygamai 5111 \\
\hline Race 6 & & F. phyllophilum 10768 \\
\hline Foc-8905, -8924, -9023, -9027 PV1, -9093 PV1 & Spain & F.poae 11470 \\
\hline Foc-9164, -9166, -9170 & Morocco & F. polyphialidicum 11414 \\
\hline Foc-Tonini & United States & F. proliferatum 11558, D-4853, D-4854 \\
\hline Foc-9620, $-9622,-9628,-9632$ & Israel & F. pseudoanthophilum 10755 \\
\hline F. oxysporum f. sp. lycopersici Fol-PV, $-325-3$ & Unknown & F. pseudocircinatum 10761 \\
\hline F. oxysporum f. sp. melonis Fom-8701, -9016 & Unknown & F. pseudograminearum 11435 \\
\hline F. oxysporum f. sp. niveum Fon- $8805,-8822$ & Unknown & F. pseudonygamai 10762 \\
\hline F. oxysporum f. sp. phaseoli Fop-DR85 & Unknown & F. ramigenum 10670 \\
\hline F. oxysporum f. sp. pisi & & F. sacchari $278, \mathrm{~B}-3852, \mathrm{~B}-3853$ \\
\hline Race 1 & & F. scirpi 11409 \\
\hline F-51, -22 & Unknown & F. semisectum 11432 \\
\hline Race 2 & & F. solani 11420 \\
\hline $\mathrm{F}-35,-42,-81$ & Unknown & F. sporotrichioides 11552 \\
\hline Race 6 & & F. subglutinans 11544, E-990, E-2192 \\
\hline F-4A, $-207,-241$ & Unknown & F. thapsinum F-4093, F-4094 \\
\hline F. oxysporum & & F. torulosum 11419 \\
\hline Nonpathogenic & & F. tricinctum 11566 \\
\hline Fo-8250, -9009, -9081, -90101, -90105, -91117 & Spain & F. verticillioides 11556, A-149, A-999 \\
\hline Fo-9169 & Morocco & \\
\hline Fo-Fsp4, -Fsp7, -Fsp8, -Fsp9 & Algeria & \\
\hline Fo-420, $-422,-425,-442,-448,-457,-506,-526,-\mathrm{C} 4 \mathrm{P}$ & Italy & \\
\hline
\end{tabular}

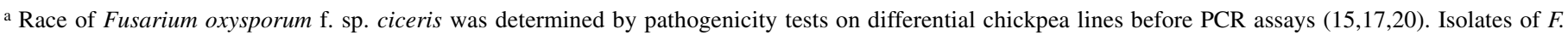
oxysporum f. spp. lycopersici Fol-PV, melonis, niveum, and phaseoli were from the fungal culture collection of Departamento de Protección de Cultivos, Instituto de Agricultura Sostenible (IAS-CSIC), Córdoba, Spain. Isolate of F. oxysporum f. sp. lycopersici Fol-325-3 was provided by D. Fravel, United States Department of Agriculture-Agricultural Research Service (USDA-ARS) Vegetable Development Laboratory, Beltsville, MD. Isolates of F. oxysporum f. sp. pisi were provided by W. Boge, USDA-ARS Pacific West Area, Prosser, WA. Isolates of other Fusarium spp. were obtained from J. F. Leslie, Department of Plant Pathology, Kansas State University, Manhattan. Geographic origin of these latter isolates was not provided. F. oxysporum isolates listed as nonpathogenic are not pathogenic to chickpea.

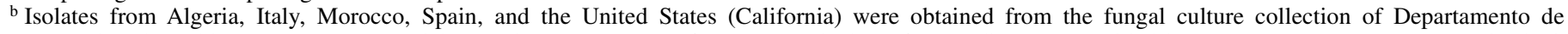
Protección de Cultivos, IAS-CSIC, Córdoba, Spain. F. oxysporum f. sp. ciceris isolates from India were provided by M. P. Haware, ICRISAT, Hyderabad, India; isolates from Tunisia were provided by M. H. Halila, Institute Nacionale de la Recherche Agronomique, Ariana, Tunisia; isolates from Israel were provided by J. Katan, Department of Plant Pathology and Microbiology, The Hebrew University of Jerusalem, Israel; isolates from Lebanon, Syria, and Turkey were provided by C. Akem, ICARDA, Aleppo, Syria; unknown = geographic origin not known. 
primed labeling (Roche Diagnostics) according to the manufacturer's instructions.

For Southern blots, 3 to $5 \mu \mathrm{g}$ of genomic DNA was digested with EcoRI. The restriction fragments were separated by electrophoresis in $0.7 \%$ agarose gels and transferred to nylon membranes using a vacuum transfer system (VacuGene XL, VacuPump, Pharmacia LKB). Hybridization conditions were as described by Sambrook et al. (33) using high-astringency temperature $\left(68^{\circ} \mathrm{C}\right)$. Homologous sequences in the fungal genome were detected by the DIG Luminescent Detection kit (Roche Diagnostics) according to the manufacturer's instructions.

Sequencing of cloned RAPD markers and design of specific SCAR primers. Cloned RAPD inserts were sequenced at the DNA Sequencing Facility at Cornell University (Ithaca, NY), or at Newbiotechnic, S.A. (Sevilla, Spain), using universal M13 and internal sequencing primers. A search for sequence similarities was performed with BLASTN and BLASTX programs of NCBI network service (1). We designed a PCR primer pair so as to correspond to sequences between 18 to 30 nucleotides that were identified at both ends of the insert. These primers included part of or the full nucleotide sequence of the Operon primer that amplified the RAPD marker originally (29). Primers were designed using the computer program PrimerSelect 3.11 (DNAStar, Lasergen, Madison, WI). Sequences for the specific primers designed in this study are shown in Table 2 and were synthesized by GENSET (Paris).

Specific PCR reactions. The PCR reaction mixture $(25 \mu \mathrm{l})$ consisted of $2.5 \mu \mathrm{l}$ of $10 \times$ reaction buffer $\left(166 \mathrm{mM}\left(\mathrm{NH}_{4}\right)_{2} \mathrm{SO}_{4}\right.$, $670 \mathrm{mM}$ Tris- $\mathrm{HCl}\left[\mathrm{pH} 8.0,25^{\circ} \mathrm{C}\right]$, Tween 20), $0.2 \mu \mathrm{M}$ of each primer, $200 \mu \mathrm{M}$ of each dNTP, 0.64 units of EcoTaq DNA
Polymerase (EcoGen, Madrid, Spain), $1.0 \mathrm{mM} \mathrm{MgCl}_{2}$, and 10 to $25 \mathrm{ng}$ of fungal DNA. Amplifications were performed in PerkinElmer 2400 and 9600 thermocyclers (Perkin-Elmer, Norwalk, CT). All reactions were repeated at least twice and always included a positive control of a known template DNA and a negative control with no DNA. Cycling profiles consisted of an initial step of $2 \mathrm{~min}$ at $94^{\circ} \mathrm{C}, 25$ or 28 cycles of $30 \mathrm{~s}$ at $94^{\circ} \mathrm{C}, 1 \mathrm{~min}$ of annealing temperature, and $30 \mathrm{~s}$ at $72^{\circ} \mathrm{C}$, followed by a final step of $4 \mathrm{~min}$ at $72^{\circ} \mathrm{C}$. Annealing temperatures were $58^{\circ} \mathrm{C}$ for the F. oxysporum f. sp. ciceris-specific primer pair (Foc0-12f/Foc0$12 \mathrm{r}$ ), and $61^{\circ} \mathrm{C}$ for specific primer pairs of races $0,1 \mathrm{~A} / 6$, and 6 of the pathogen (Table 2). For the race 5-specific primer pair (FocR5-L10f/FocR5-L10r), we used a touchdown-PCR procedure (6) to ensure specificity of the amplification product. For this procedure, the annealing temperature was $71^{\circ} \mathrm{C}$ for the first PCR cycle and decreased by $1{ }^{\circ} \mathrm{C}$ per cycle for the next 10 cycles until an optimal annealing temperature of $61^{\circ} \mathrm{C}$ was reached. Then, there were $15 \mathrm{PCR}$ cycles at the annealing temperature of $61^{\circ} \mathrm{C}$, as described previously. PCR amplification products were separated and visualized as described above for the RAPD reactions.

\section{RESULTS}

Cloning and hybridization of RAPD markers. JiménezGasco et al. (17) identified the following specific RAPD markers for $F$. oxysporum f. sp. ciceris and each of the pathogenic races: $F$. oxysporum f. sp. ciceris, $1.5 \mathrm{~kb}(\mathrm{OPF}-12)$; race $0,0.39 \mathrm{~kb}(\mathrm{OPF}-$ 12) and $0.9 \mathrm{~kb}(\mathrm{OPI}-09)$; race $1 \mathrm{~B} / \mathrm{C}, 0.53 \mathrm{~kb}(\mathrm{OPI}-09)$ and $1.1 \mathrm{~kb}$ (OPF-10); race 5, $0.9 \mathrm{~kb}(\mathrm{OPF}-10)$; and race 6, 1.0 and $1.4 \mathrm{~kb}$

TABLE 2. GenBank accession numbers of sequence characterized amplified regions (SCARs), characteristics of recombinant DNA bacterial plasmids, SCAR primers, and amplification conditions for specific polymerase chain reaction assays developed for the identification of Fusarium oxysporum f. sp. ciceris and races $0,1 \mathrm{~A}, 1 \mathrm{~B} / \mathrm{C}, 5$, and 6

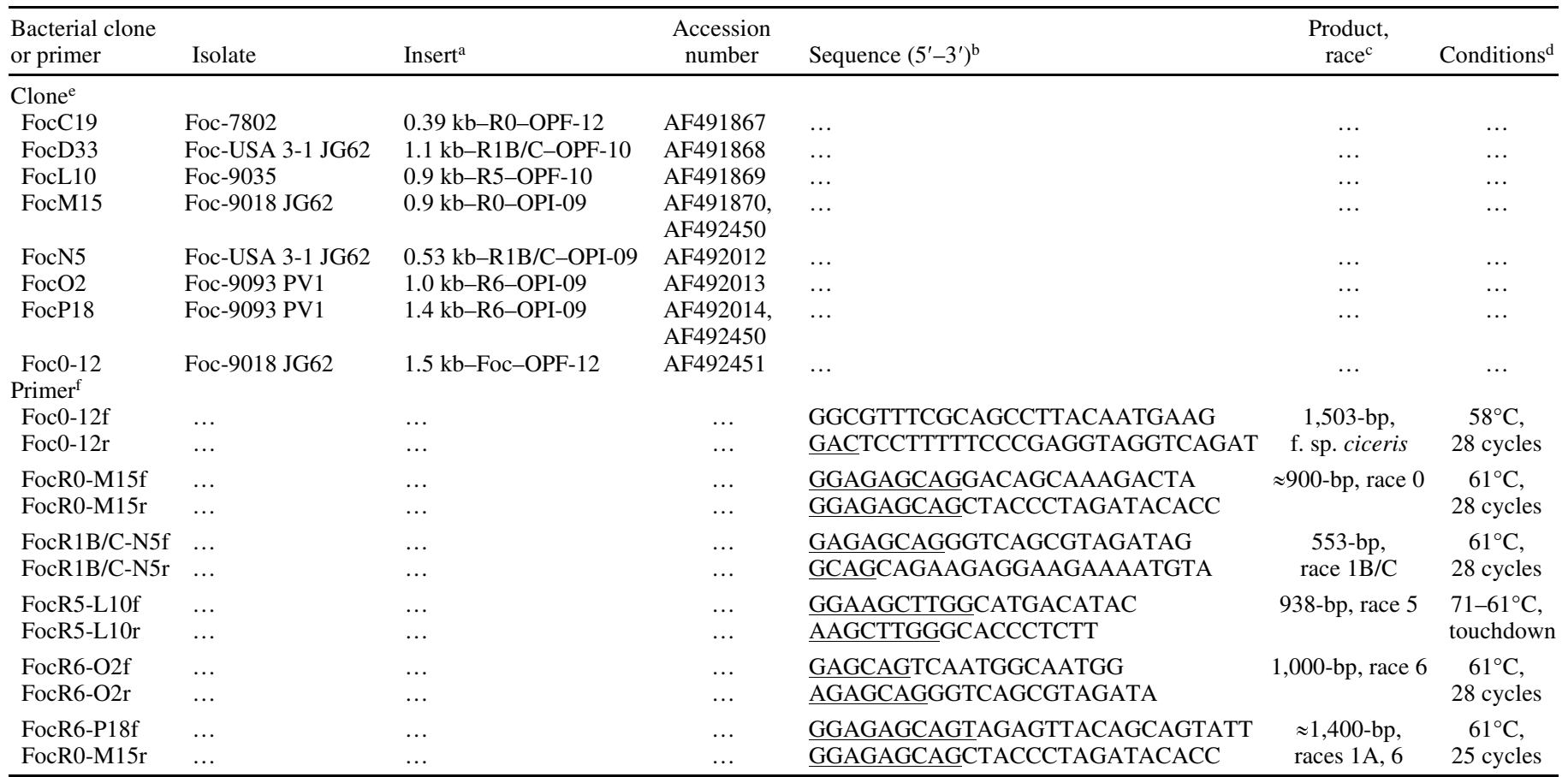

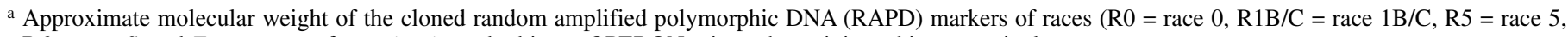

$\mathrm{R} 6=$ race 6 ) and $F$. oxysporum f. sp. ciceris, and arbitrary OPERON primer that originated it, respectively.

${ }^{\mathrm{b}}$ Underlined nucleotides indicate sequences of the corresponding arbitrary primers.

c Polymerase chain reaction (PCR) product and race from which amplified.

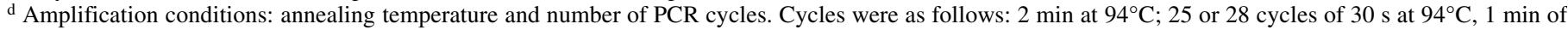
annealing temperature, and $30 \mathrm{~s}$ at $72^{\circ} \mathrm{C}$; and a final step of $4 \mathrm{~min}$ at $72^{\circ} \mathrm{C}$. Touchdown PCR (6) consisted of 2 min at $94{ }^{\circ} \mathrm{C}$; $10 \mathrm{cycles}$ at decreasing annealing temperature $\left(71\right.$ to $\left.61^{\circ} \mathrm{C}\right) ; 15$ cycles of $30 \mathrm{~s}$ at $94^{\circ} \mathrm{C}, 1 \mathrm{~min}$ at $61^{\circ} \mathrm{C}$, and $30 \mathrm{~s}$ at $72{ }^{\circ} \mathrm{C}$; followed by $4 \mathrm{~min}$ at $72^{\circ} \mathrm{C}$.

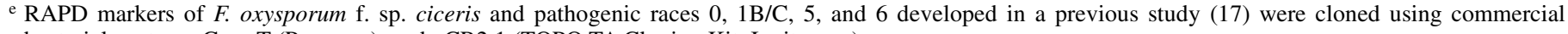
bacterial vectors pGem-T (Promega), and pCR2.1 (TOPO TA Cloning Kit, Invitrogen).

${ }^{\mathrm{f}}$ Primers nomenclature: race of $F$. oxysporum f. sp. ciceris identified and bacterial clone from which the sequences were designed. 
(OPI-09). Cloning of these RAPD marker bands into a bacterial vector yielded three to six types of different DNA inserts from a cloned RAPD band. These DNA inserts were distinguished because of slight differences in molecular size, and the distinct restriction patterns of inserts digested with ApaI, BamHI, EcoRI, PstI, SacI, and XbaI endonucleases. Hybridization of the RAPD patterns that contained the marker DNA band for $F$. oxysporum $\mathrm{f}$. sp. ciceris and for its races $0,1 \mathrm{~B} / \mathrm{C}, 5$, and 6 , using as probes each of DNA inserts derived from cloning of the corresponding RAPD marker, allowed to identify the relevant marker sequences. In all cases, only one of the inserts hybridized to the corresponding RAPD marker. Other insert DNAs hybridized to RAPD products of similar molecular weight that were amplified from all the races tested but were not distinguishable in the agarose gels following electrophoretic separation. The above results allowed selection of bacterial clones carrying inserts corresponding to each of $F$. oxysporum $\mathrm{f}$. sp. ciceris and races $0,1 \mathrm{~B} / \mathrm{C}, 5$, and 6 (Table 2).

Inserts from clones FocD33, FocL10, FocN5, FocO2, and Foc012 hybridized strongly with the single RAPD marker band amplified from isolates of the appropriate race, and this signal corresponded in size to that of the progenitor RAPD fragment (Fig. 1). Therefore, these inserts were appropriate for the identification of the corresponding $F$. oxysporum f. sp. ciceris race. Conversely, clone FocC19 derived from the race 0 RAPD marker
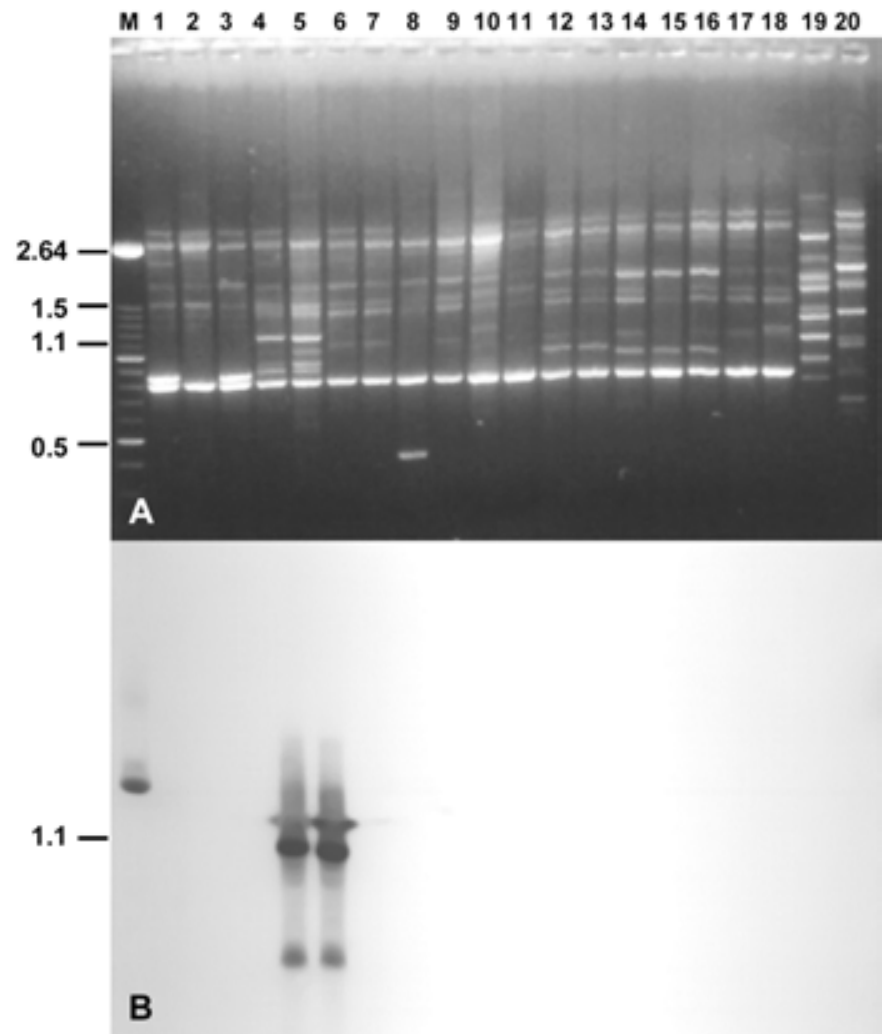

Fig. 1. A, Random amplified polymorphic DNAs (RAPDs) generated by primer OPF-10 using genomic DNA of isolates of Fusarium oxysporum $\mathrm{f}$. sp. ciceris and of nonpathogenic $F$. oxysporum; and $\mathbf{B}$, hybridization and chemiluminescence detection results using the same gel as in A and the DNA insert FocD33 derived from the cloned race 1B/C-RAPD marker of $1.1 \mathrm{~kb}$ as a probe. Numbers on the left are the molecular weights $(\mathrm{kb})$ of the $0.1-\mathrm{kb}$ ladder XIV (Roche Diagnostics) (lane M). Lanes correspond to the following isolates: lanes 1 to 3, race 0 Foc-8207, -9018 JG62, and -7952; lanes 4 to 5, race 1B/C Foc-USA 3-1 JG62, and -1987 W17; lane 6, race 1A Foc-7989; lane 7, race 6 Foc-9166; lanes 8 to 9, race 2 Foc-8605 and -1992R2N; lanes 10 to 11 , race 3 Foc- 8606 and $-1992 \mathrm{R} 3 \mathrm{~N}$; lanes 12 to 13 , race 4 Foc- 8607 and -1992R4N; lanes 14 to 16, race 5 Foc-8012, -9035, and -USA 1-1 JG62; lanes 17 to 18, race 6 Foc-9023 and -Tonini; and lanes 19 to 20, nonpathogenic Fo-9009 and -90105 . amplified by OPF-12 hybridized to this fragment from all race 0 isolates as expected, but it also hybridized to DNA bands amplified by this primer from other $F$. oxysporum f. sp. ciceris races as well as from $F$. oxysporum isolates nonpathogenic to chickpea. However, none of the FocC19-hybridized amplicons of above were distinguishable after separation of the RAPD products in agarose gels. Therefore, the insert carried by clone FocC19 was not suitable for identification of race 0 and was disregarded for further investigations. Finally, inserts from clones derived from race 0 (FocM15) and race 6 (FocP18) marker bands amplified by primer OPI-09 (Table 2) produced a faint cross-hybridization signal when probed against the RAPD patterns generated by OPI09 from isolates of these races. However, these clones did not hybridize with any other amplicon. Subsequent nucleotide sequence analysis showed that these two insert DNAs share a short identical sequence.

Southern hybridizations of EcoRI-digested genomic DNA from isolates of $F$. oxysporum $\mathrm{f}$. sp. ciceris races using the inserts as probes allowed characterization of the following insert DNAs as moderate to highly repetitive (20 to 30 bands, 1.5 to $12.0 \mathrm{~kb}$ in size) DNAs (8): FocD33, FocM15, FocN5, FocO2, and FocP18. The genome of each of the races tested shared homologies to all insert DNAs of above, but the hybridization patterns showed racespecific polymorphisms (i.e., for every insert DNA of above the hybridization patterns showed higher similarity among isolates of a race compared with that with isolates of different races). Similarly, hybridization of EcoRI-digested genomic DNA from nonpathogenic $F$. oxysporum isolates Fo-420, -8250, -9009, -9081, -90105 , and -9169 using the inserts from clones FocD33, FocM15, FocN5, FocO2, and FocP18 (Table 2) as probes indicated that the genomes of these isolates, except for isolate Fo-9009, also comprised homologous sequences to the insert DNAs listed above. Isolate Fo-9009 genomic DNA showed no homology to any of the insert DNAs (Table 2). Homologies in nonpathogenic $F$. oxysporum occurred in a smaller number of copies and displayed completely different hybridization patterns compared with those in F. oxysporum f. sp. ciceris (Fig. 2).

Clones FocL10 and Foc0-12 did not exhibit repetitive copies. They hybridized only to one to four bands in the EcoRI-digested DNA of $F$. oxysporum f. sp. ciceris isolates, depending upon the race, and to one band in that of nonpathogenic $F$. oxysporum isolates (only clone FocL-10) (Fig. 3). Contrary to the rest of the DNA sequences, the insert from Foc0-12 did not hybridize with any fragments from the EcoRI-digested genomic DNA of nonpathogenic $F$. oxysporum isolates. This insert was selected for the identification of $F$. oxysporum f. sp. ciceris.

Sequencing of cloned RAPD markers and design of SCAR primers specific for $F$. oxysporum f. sp. ciceris and its pathogenic races $\mathbf{0}, \mathbf{1 B} / \mathbf{C}, \mathbf{5}$, and 6 . The complete (clones FocD33, FocL10, FocN5, FocO2, and Foc0-12) or partial ( $5^{\prime}$ and $3^{\prime}$ ends; clones FocM15 and FocP18) sequences of insert DNAs were obtained and compared with the GenBank database for the identification of sequence similarity to published gene sequences (1). The insert from clone $\mathrm{FocO} 2$ showed $45 \%$ nucleotide similarity with a transposase-like protein identified in F. oxysporum (28). The inserts from clones FocM15 and FocP18 shared a fragment of identical nucleotide sequence, which was identified as a portion of the impala transposon reported in F. oxysporum (21) in a BLAST search. Also, a BLAST search showed similarity of the Foc10L sequence to several transport proteins. The complete and partial sequences were deposited in the GenBank nucleotide sequence database (accession numbers, Table 2). From the complete and partial sequences of the clones we designed seven specific primer pairs for the identification of $F$. oxysporum f. sp. ciceris (primer pair Foc0-12f/Foc0-12r) and of the pathogenic races 0 (primer pair FocR0-M15f/FocR0-M15r), 1B/C (primer pairs FocR1B/ C-N5f/FocR1B/C-N5r and FocR1B/C-D33f/FocR1B/C-D33r), 5 (primer pair FocR5-L10f/FocR5-L10r), and 6 (primer pairs 
FocR6-O2f/FocR6-O2r and FocR6-P18f/FocR6-P18r) by specific PCR assays. Primer designation and sequences, target races, and PCR products under optimized amplification conditions are presented in Table 2.

Identification of $F$. oxysporum f. sp. ciceris and its pathogenic races $0,1 A, 5$, and 6 by SCAR primers. Primers derived from sequences of inserts in clones FocM15, FocN5, FocL10, and FocO2 amplified only a single PCR product from genomic DNA of isolates of each of races $0,1 \mathrm{~B} / \mathrm{C}, 5$, and 6, respectively (Fig. 4). None of these products were amplified when DNA of isolates of F. oxysporum f. sp. ciceris races other than the target races, and of nonpathogenic isolates of $F$. oxysporum, were used as template in specific PCR assays (Fig. 4). Similarly, the primer pair Foc0$12 \mathrm{f} / \mathrm{Foc} 0-12 \mathrm{r}$ selectively amplified only a single 1,503 -bp product from the genomic DNA of a large number of $F$. oxysporum $\mathrm{f}$. sp. ciceris isolates representative of all races of the pathogen and of a wide geographic range. This primer pair was designed for the specific identification of the forma specialis ciceris. Conversely, SCAR primer pairs based on sequences from the inserts in clones

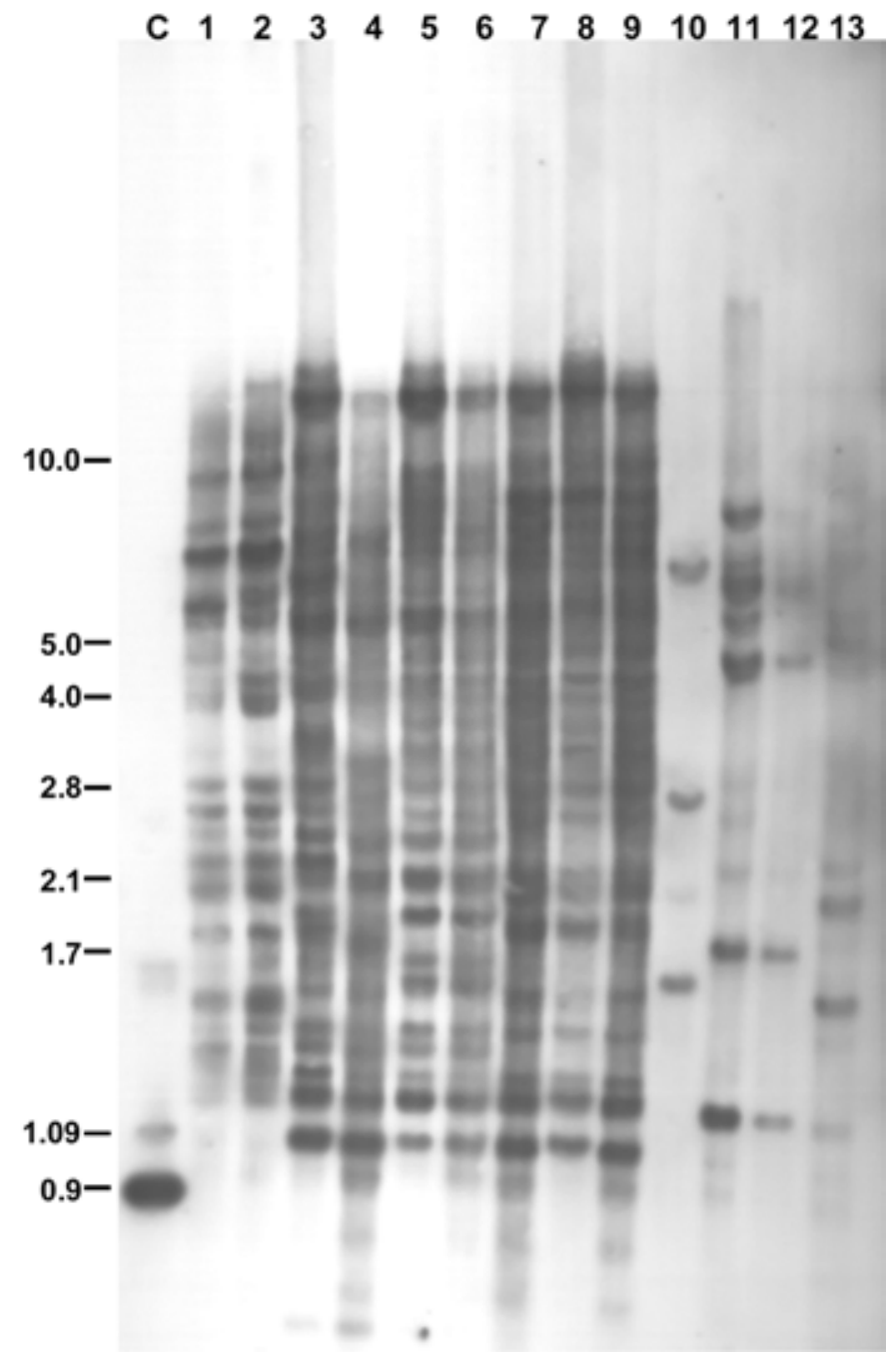

Fig. 2. Southern blot hybridization and chemiluminescence detection results of EcoRI-digested genomic DNA of representative isolates of Fusarium oxysporum f. sp. ciceris and nonpathogenic F. oxysporum. Hybridization probe was the insert DNA FocO2 derived from the cloned race 0 random amplified polymorphic DNA marker of $1.0 \mathrm{~kb}$. Numbers on the left are approximate molecular weights $(\mathrm{kb})$. Lanes correspond to the following isolates: lanes 1 to 2, race 0 Foc-9018 PV1 and -T3; lane 3, race 3 Foc-8606; lane 4, race 4 Foc-8607; lanes 5 to 6 , race 5 Foc-USA 1-1 JG62 and -USA W6-1; lanes 7 to 9, race 6 Foc-9164, -9023, and -9093 PV1; lanes 10 to 13, nonpathogenic Fo-8250, -9081, -9169, and -420. Lane C is a positive hybridization control (DNA of the corresponding hybridization probe).
FocD33 and FocP18 amplified a single PCR product from all races of $F$. oxysporum $\mathrm{f}$. sp. ciceris, although these primers were originally designed for the specific identification of races $1 \mathrm{~B} / \mathrm{C}$ and 6, respectively. This result was unexpected because hybridization assays of RAPD patterns from the eight pathogen races using the above insert DNAs as probes showed hybridization signals only for races $1 \mathrm{~B} / \mathrm{C}$ and 6 , and negative results otherwise.

To verify that heterologous amplifications do not occur in the specific PCR assays, specific PCR products from isolates representative of the eight pathogenic races of $F$. oxysporum f. sp. ciceris, $F$. oxysporum nonpathogenic to chickpea, other $F$. oxysporum formae speciales, and other Fusarium spp. (Table 1) were hybridized using the corresponding insert DNAs as probes. Specific PCR assays using single DNA from isolates of the above and primer pairs FocR0-M15f/FocR0-M15r, FocR1B/C-N5f/ FocR1B/C-N5r, and FocR6-O2f/FocR6-O2r yielded the predicted single products only from DNA of races $0,1 \mathrm{~B} / \mathrm{C}$, and 6 , respectively. Furthermore, only these amplification products yielded a signal in the hybridizations using the corresponding insert DNA as probes. There were no hybridization signals detectable when these later probes were used for hybridization of the putative PCR products from isolates of other F. oxysporum f. sp. ciceris races, nonpathogenic $F$. oxysporum, other $F$. oxysporum formae speciales, and other Fusarium spp. Results were similar with primer pair Foc0-12f/Foc0-12r (Fig. 5). Hybridization of the insert from clone FocL10 to the specific-PCR products yielded by primer pair FocR5-L10f/FocR5-L10r from the same fungal DNAs mentioned above indicated that amplification occurred for isolates of the target race 5 but also for isolates of other races. However, the hybridization signals produced by the nonspecific amplification products were of much less intensity compared with that produced by race 5 isolates. This difficulty was overcome by touchdown PCR (6), which increased the specificity of the amplification to the point that only the race 5-diagnostic amplicon hybridized to the insert from clone FocL10 (Fig. 4B). These results indicated that the SCAR primer pairs designed are effective for the specific identification of $F$. oxysporum $\mathrm{f}$. sp. ciceris and of its pathogenic races $0,1 \mathrm{~B} / \mathrm{C}, 5$, and 6 by specific- and touchdownPCR assays. In addition, PCR assays using primers FocR6-P18f

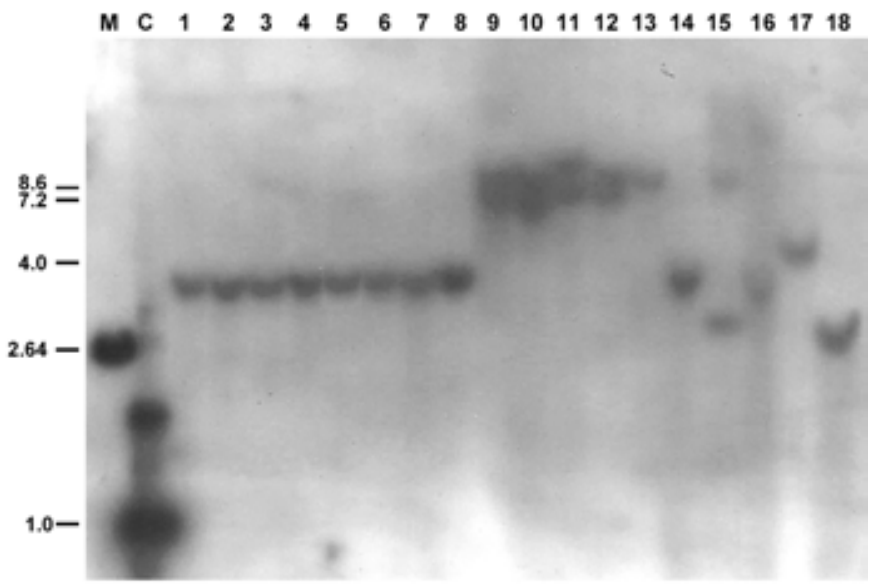

Fig. 3. Southern blot hybridization and chemiluminescence detection results of EcoRI-digested genomic DNA of representative isolates of Fusarium oxysporum $\mathrm{f}$. sp. ciceris and nonpathogenic $F$. oxysporum. Hybridization probe was insert DNA FocL10 derived from the cloned race 5 random amplified polymorphic DNA marker of $0.9 \mathrm{~kb}$. Numbers on the left are approximate molecular weights $(\mathrm{kb})$. Lanes correspond to the following isolates: lanes 1 to 2 , race 0 Foc- 8207 and -82018 ; lane 3, race $1 \mathrm{~B} / \mathrm{C} \mathrm{Foc-}$ 1987 W-17; lane 4, race 2 Foc-1992R2N; lane 5, race 4 Foc-1992R4N; lanes 6 to 8 , race 1A Foc-7989, -9166 , and -9027 PV1; lanes 9 to 13, race 5 Foc8012, -USA 1-1 JG62, -USA W6-1, -9035, and -9094 JG62; lanes 14 and 16, race 6 Foc-Tonini and -9093 PV1; lanes 15, 17, and 18, nonpathogenic Fo8250, -9009, and -90105. Lane C is a positive hybridization control (DNA of the corresponding hybridization probe). 
and FocR0-M15r yielded a single product of approximately 1,400 -bp only from genomic DNA of isolates of $F$. oxysporum $\mathrm{f}$. sp. ciceris races R1A and 6 (Fig. 4D). Therefore, a positive result from this assay strategy, together with a negative result from PCR assay using the race 6-specific primers pair FocR6-O2f/FocR6$\mathrm{O} 2 \mathrm{r}$, will allow the identification of race $1 \mathrm{~A}$ isolates, albeit in a two-step process.

The specificity and reliability of the SCAR primers developed in this study for the identification of $F$. oxysporum $\mathrm{f}$. sp. ciceris and its races $0,1 \mathrm{~B} / \mathrm{C}, 1 \mathrm{~A}, 5$, and 6 was further challenged by additional PCR assays using a large collection of Fusarium isolates (Table 1). No cross-reactions or amplification of additional fragments were observed for isolates of other $F$. oxysporum formae speciales, other Fusarium spp., and nonpathogenic $F$. oxysporum. Furthermore, the specific PCR assays correctly identified isolates of $F$. oxysporum $\mathrm{f}$. sp. ciceris and assigned them to the correct pathogenic race. Nevertheless, these PCR assays proved problematic for some of the tested isolates. Primer pair FocR1B/ C-N5f/FocR1B/C-N5r yielded a single PCR product of 553-bp from race $1 \mathrm{~B} / \mathrm{C}$ isolates originating from California that was not amplified from isolates of the same race of other geographic origin (i.e., Israel, Syria, Tunisia, or Turkey). Races 2, 3, and 4 were beyond the scope of this work. These three races have been reported only in India (12) and only two isolates of each of them were made available to us. Results from two isolates were not considered appropriate for the aims of our research. Finally, we tested the PCR assays developed in this study using a range of DNA from 200 to $10^{-5} \mathrm{ng}$ to determine the minimum amount of fungal genomic DNA that could be detected. Every primer pair designed in this study detected a minimum amount of $0.1 \mathrm{ng}$ of fungal DNA (Fig. 6).

\section{DISCUSSION}

Phenotypic and genetic characterization of $F$. oxysporum f. sp. ciceris races is important for the efficient management of Fusarium wilt through use of resistant cultivars in chickpea-growing areas. This study demonstrated that SCAR primers developed from RAPD markers (17) can be used to unambiguously identify F. oxysporum f. sp. ciceris races $0,1 \mathrm{~A}, 5$, and 6, which are prevalent in the Mediterranean Basin (17). Also, these SCAR primers proved useful in discriminating $F$. oxysporum f. sp. ciceris from other diverse formae speciales of this species, other Fusarium spp., and nonpathogenic $F$. oxysporum. The SCAR primer pairs amplified a single diagnostic PCR product from all isolates of the target forma specialis and races irrespective of the geographic origin. This is the first report of PCR-based identification of $F$. oxysporum f. sp. ciceris. Although races 0,5 , and 6 can be characterized by the RAPD markers previously reported (17), the SCAR primers and PCR assays are free of problems associated with RAPD assays that reduce its applicability for diagnosis of those races and enhance the possibility of fast, extensive, and reliable discrimination of the pathogen and races. An additional benefit from the present study concerns the molecular identification of race $1 \mathrm{~A}$ of the pathogen, for which no RAPD marker was found previously (17). This can be achieved through two independent

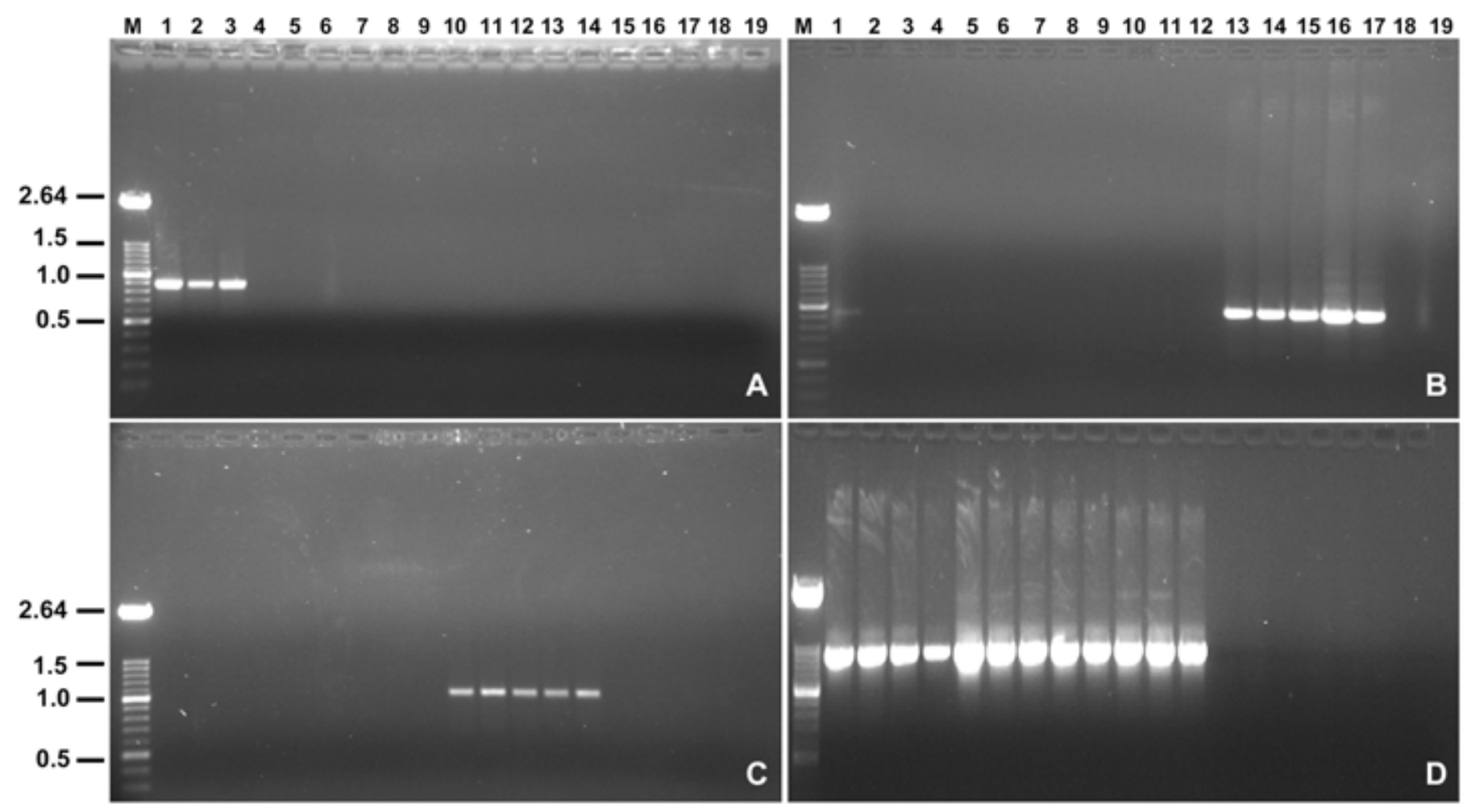

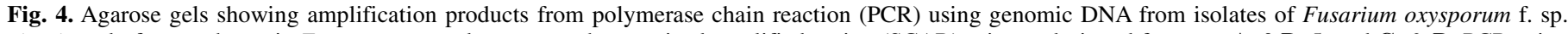

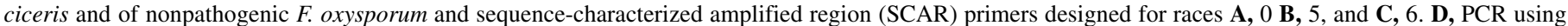

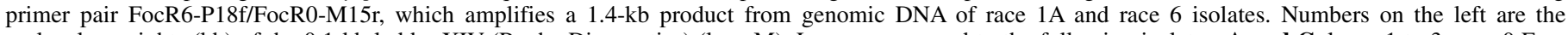

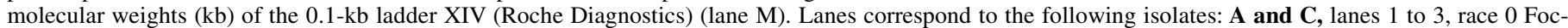

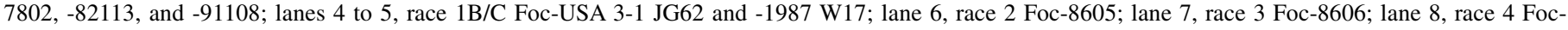

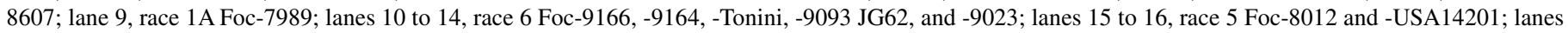

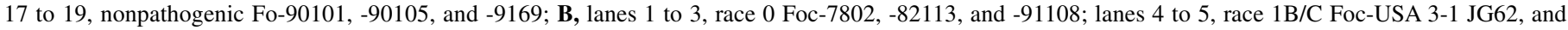

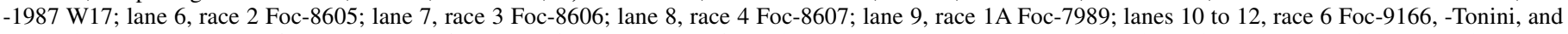

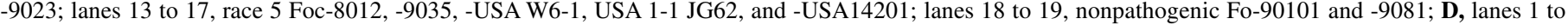

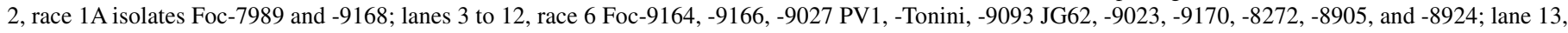

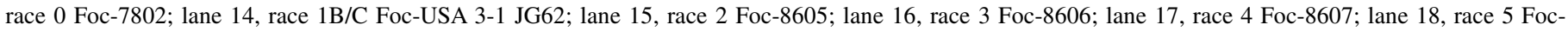
8012; and lane 19, nonpathogenic Fo-90105. 
PCR assays, one using the SCAR primers which amplified a single PCR product from races $1 \mathrm{~A}$ and 6 , and another assay using the race 6 -specific primers. Races $1 \mathrm{~A}$ and 6 showed close virulence patterns on chickpea differentials $(11,15)$ and high genetic similarities by RAPD analyses (17). This could explain the occurrence of a common specific PCR marker.

An unexpected, though interesting result in our study concerns the SCAR primer pair FocN5-R1B/Cf/FocN5-R1B/Cr. These primers were developed for the identification of race $1 \mathrm{~B} / \mathrm{C}$ and amplified a single $\mathrm{PCR}$ product from race $1 \mathrm{~B} / \mathrm{C}$ isolates from California but not from those from other geographic origins (i.e., Israel, Syria, Tunisia, and Turkey). Races 0 and $1 \mathrm{~B} / \mathrm{C}$ induce the yellowing syndrome in chickpea and share high genetic similarity, as indicated by cluster analysis of RAPD amplifications (17). The limitations of pathogenicity assays may have led to misclassification of race 0 and race $1 \mathrm{~B} / \mathrm{C}$ isolates (19). Therefore, additional work, including new pathogenicity tests, must be done to clarify the race identity of the above isolates as well as to ascertain the possibility that significant genetic diversity may exist among isolates of race $1 \mathrm{~B} / \mathrm{C}$ from different geographic origin.

Our study illustrates the need for extreme caution in the process of selecting the appropriate cloned DNA fragments, a crucial step in the design of race-specific SCAR primers from RAPD markers. The methodology used had a critical impact on the possibility of achieving our research goals; therefore, it deserves special men-

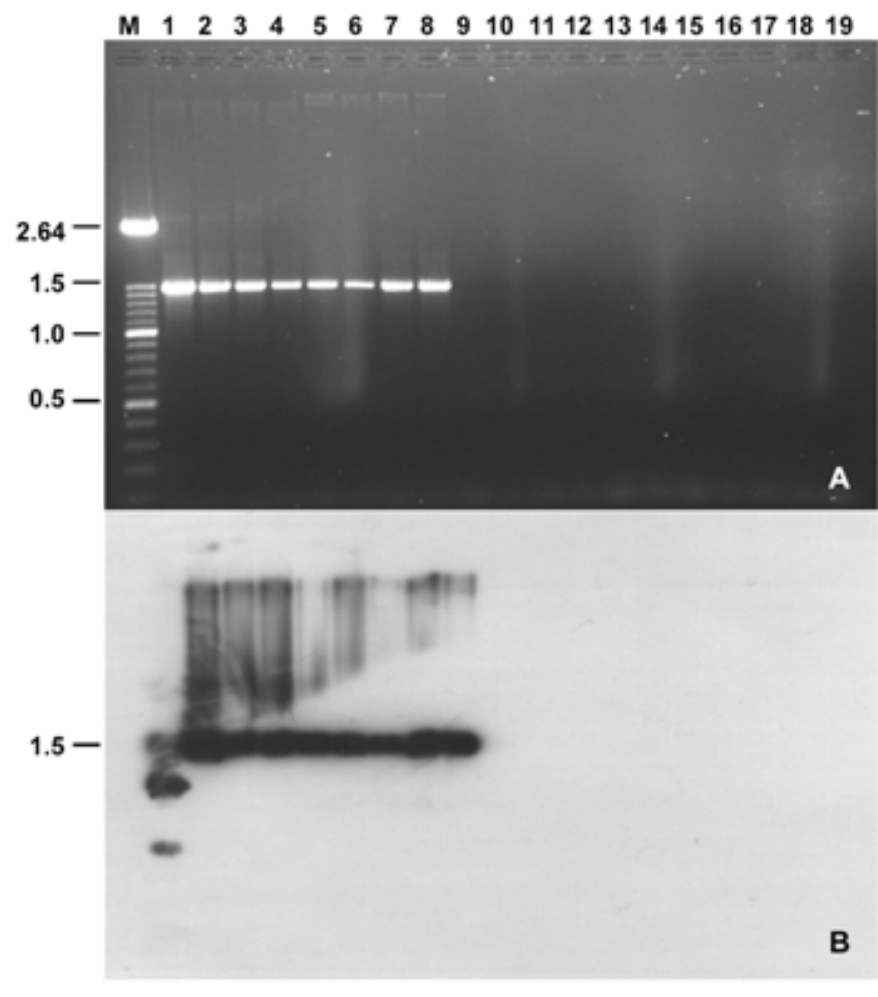

Fig. 5. A, Agarose gel showing the $1.5-\mathrm{kb}$ product diagnostic for Fusarium oxysporum f. sp. ciceris using genomic DNA from $F$. oxysporum f. sp. ciceris isolates and isolates of nonpathogenic $F$. oxysporum, and sequencecharacterized amplified region (SCAR) primer pair Foc0-12f/Foc0-12r; and $\mathbf{B}$, hybridization and chemiluminescence detection results using the same gel as in $\mathbf{A}$ and the insert DNA Foc0-12 derived from the cloned random amplified polymorphic DNA marker of $1.5 \mathrm{~kb}$. Numbers on the left are the molecular weights $(\mathrm{kb})$ of the 0.1-kb ladder XIV (Roche Diagnostics) (lane M). Lanes 1 to 8 correspond to F. oxysporum f. sp. ciceris isolates Foc-7802 (race 0), -USA 3-1 JG62 (race 1B/C), -7989 (race 1A), -8605 (race 2), -8606 (race 3), -8607 (race 4), -8012 (race 5), and -9023 (race 6). Lanes 9 to 12 correspond to nonpathogenic F. oxysporum isolates Fo-8250, -9081, -90105, and -506. Lanes 13 and 14 correspond to isolates $F$. oxysporum f. sp. melonis 9016 and $F$. oxysporum f. sp. niveum 8805. Lanes 15 to 19 correspond to isolates $F$. acuminatum 11442, F. avenaceum 11440, F. lactis 10757, F. proliferatum 11558 , and $F$. solani 11420 . tion. Restriction analyses of a large number of DNA inserts derived from each cloning experiment showed nonhomologous DNA sequences within each RAPD marker. Thereafter, hybridization of RAPD profiles using each resulting insert as a probe showed that many sequences also were amplified in pathogen races other than the target race, which allowed us to identify clones containing the race-specific DNA inserts and discard the nonspecific ones. Had these precautions not been taken, inadequate sequences for primer design might have been chosen, which would have resulted in the development of nonspecific primers and PCR assays.

It often is assumed that DNA fragments of the same molecular size amplified in RAPD assays represent homologous sequences. This assumption is not necessarily correct and homology of RAPD bands needs to be demonstrated using Southern analyses (32). Using this procedure, we herein verified that the RAPD bands amplified from isolates of the target forma specialis or belonging to the same race were homologous. This strengthens the suitability of our approach for developing race-specific SCAR primers and PCR assays from informative RAPD fragments.

Repetitive DNA sequences have been used before to successfully identify subpopulations within fungal species, including $F$. oxysporum $(4,7,25)$. The efficiency of such repetitive sequences for generating SCAR markers has been demonstrated previously for the detection of Peronospora tabacina by specific PCR (36). Although sequences derived from the RAPD marker of a particular F. oxysporum f. sp. ciceris race were present in a high-copy number in the genome of all the races of the pathogen, we were able to design SCAR primers that yielded race-specific PCR products. Thus, the single 900- and 1,000-bp products of primer pairs FocR0-M15f/FocR0-M15r and FocR6-O2f/FocR6-O2r that identify races 0 and 6 , respectively, were proven specific by hybridization experiments of the blotted PCR products. Primer pair FocR5-L10f/FocR5-L10r was based on a single- or low-copy DNA fragment. These primers yielded a single 900-bp product that was diagnostic for race 5. Although this product also was amplified from other $F$. oxysporum $\mathrm{f}$. sp. ciceris races, that was to a much lesser extent because it could be detectable only by hybridization of the PCR products. A touchdown-PCR procedure significantly improved the intensity of the amplification signal and the specificity of this assay, making it suitable for the selective identification of race 5 (6).

That DNA sequences from all RAPD markers studied herein were present in the genome of the eight pathogen races, irrespective of geographic origin, was not surprising. Previous studies showed that races of $F$. oxysporum $\mathrm{f}$. sp. ciceris share the same mitochondrial DNA restriction fragment length polymorphism

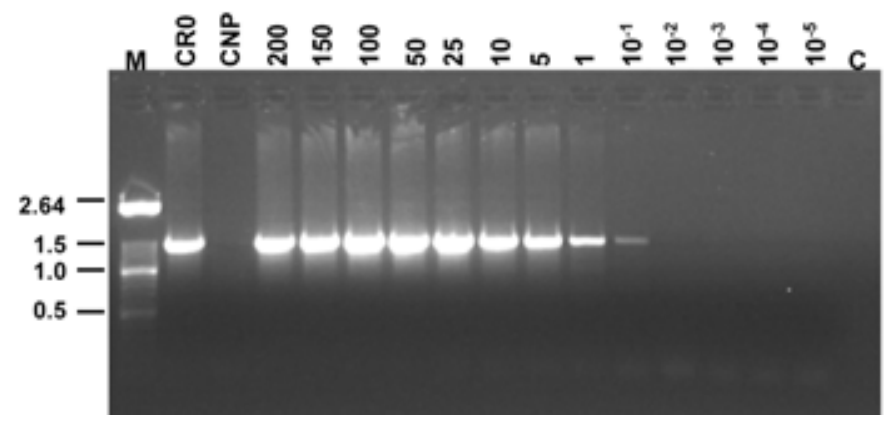

Fig. 6. Agarose gel showing the sensitivity of polymerase chain reaction (PCR) using genomic DNA of Fusarium oxysporum f. sp. ciceris and sequence-characterized amplified region (SCAR) primer pair Foc0-12f/Foc012r: Amplification of decreasing amount of race 0 isolate Foc-7802 DNA ranging from 200 to $10^{-5} \mathrm{ng}$. Numbers on the left correspond to the molecular weights $(\mathrm{kb})$ of the 0.1-kb ladder XIV (Roche Diagnostics) (lane $\mathrm{M})$. Lanes CR0 and CNP, amplification controls for race 0 isolate Foc-7802 and nonpathogenic F. oxysporum isolate Fo-90101 DNAs, respectively. Lane $\mathrm{C}$, control reaction with no template DNA. 
pattern (30) and belong to a single vegetative compatibility group (27). Additionally, sequence analyses of five nuclear genes and further gene genealogy analysis of the translation elongation factor $1 \alpha$ indicated a monophyletic origin of $F$. oxysporum $\mathrm{f}$. sp. ciceris (16). Therefore, isolates of this strictly asexually reproducing fungus probably derived from a small founder population or single individual that acquired pathogenicity to Cicer spp., and populations that further developed likely comprise clonal individuals that share a common genetic background (9).

Numerous studies have demonstrated the utility of RAPD methodology for correlating molecular markers to pathogenic races in $F$. oxysporum $(2,10,22)$. However, the number of studies that subsequently have converted race-associated RAPD markers into SCARs and have developed specific primers for race identification is more limited (5). Our results proved that this strategy is highly efficient, for it allowed the unambiguous differentiation of races within a monophyletic forma specialis of $F$. oxysporum, as well as the discrimination of the forma specialis itself from other F. oxysporum and Fusarium spp. Also, our results have important practical applications for diagnosis, epidemiology, and management of Fusarium wilt of chickpea. Thus, the SCAR primers specific for F. oxysporum f. sp. ciceris provide a useful tool for easily discriminating nonpathogenic $F$. oxysporum isolates that can be recovered from virus-infected chickpea $(18,34)$, as well as from Fusarium wilt-affected chickpea (34). Similarly, the racespecific SCAR primers provide an attractive alternative for the analysis of race structure in F. oxysporum f. sp. ciceris populations compared with the use of pathogenicity tests. The racespecific PCR products of these SCAR primers should facilitate the early detection of introduced races, as well as detect changes in the relative race frequencies that may occur as a response to the use of resistant cultivars. Finally, all SCAR primer pairs developed were able to detect $0.1 \mathrm{ng}$ of fungal DNA using the amplification conditions described herein. Such amounts of fungal DNA can be obtained easily from several natural substrates that harbor the pathogen. Relatively straightforward adaptations of this technique could be envisioned for the detection of races of $F$. oxysporum f. sp. ciceris in infested soil or in infected plants (20), which will find additional practical applications in the epidemiology and management of Fusarium wilt of chickpea.

\section{ACKNOWLEDGMENTS}

This research was supported by grants AGF97-1479 and AGF98-0878 from Comisión Interministerial de Ciencia y Tecnología (CICYT) of Spain. We thank G. Contreras for technical support; C. Akem, W. Boge, D. Fravel, M. H. Halila, J. Katan, and J. F. Leslie for providing fungal isolates; and $\mathrm{E}$. Manias for critical reading of the manuscript.

\section{LITERATURE CITED}

1. Altschul, S. F., Madden, T. L., Schäffer, A. A., Zhang, J., Zhang, Z., Miller, W., and Lipman, D. J. 1997. Gapped BLAST and PSI-BLAST: A new generation of protein database search programs. Nucleic Acids Res. 25:3389-3402.

2. Assigbetse, K. B., Fernandez, D., Dubois, M. P., and Geiger, J. P. 1994. Differentiation of Fusarium oxysporum $\mathrm{f}$. sp. vasinfectum races on cotton by random amplified polymorphic DNA (RAPD) analysis. Phytopathology 84:622-626.

3. Bunting, T. E., Plumley, K. A., Clarke, B. B., and Hillman, B. I. 1996. Identification of Magnaporthe poae by $\mathrm{PCR}$ and examination of its relationship to other fungi by analysis of their nuclear rDNA ITS-1 regions. Phytopathology 86:398-404.

4. Chiocchetti, A., Bernardo, I., Daboussi, M. J., Garibaldi, A., Gullino, M. L., Langin, T., and Migheli, Q. 1999. Detection of Fusarium oxysporum f. sp. dianthi in carnation tissue by PCR amplification of transposon insertions. Phytopathology 89:1169-1175.

5. de Haan, L. A. M., Numansen, A., Roebroek, E. J. A., and van Doorn, J. 2000. PCR detection of Fusarium oxysporum f. sp. gladioli race 1, causal agent of Gladiolus yellows disease, from infected corms. Plant Pathol. 49:89-100.
6. Don, R. H., Cox, P. T., Wainwright, B. J., Baker, K., and Mattick, J. S. 1991. 'Touch-down' PCR to circumvent spurious priming during gene amplification. Nucleic Acids Res. 19:4008.

7. Edel, V., Steinberg, C., Avelange, I., Laguerre, G., and Alabouvette, C. 1995. Comparison of three methods for the characterization of Fusarium oxysporum strains. Phytopathology 85:579-585.

8. Goodwin, S. B., Drench, A., and Fry, W. E. 1992. Cloning and genetic analysis of two highly polymorphic, moderately repetitive nuclear DNAs from Phytophthora infestans. Curr. Genet. 22:107-115.

9. Gordon, T. R., and Martyn, R. D. 1997. The evolutionary biology of Fusarium oxysporum. Annu. Rev. Phytopathol. 35:111-128.

10. Grajal-Martín, M. J., Simon, C. J., and Muehlbauer, F. J. 1993. Use of random amplified polymorphic DNA (RAPD) to characterize race 2 of Fusarium oxysporum f. sp. pisi. Phytopathology 83:612-614.

11. Halila, H. M., and Strange, R. N. 1996. Identification of the causal agent of wilt of chickpea in Tunisia as Fusarium oxysporum $\mathrm{f}$. sp. ciceris race 0. Phytopathol. Mediterr. 35:67-74.

12. Haware, M. P., and Nene, Y. L. 1982. Races of Fusarium oxysporum f. sp. ciceris. Plant Dis. 66:809-810.

13. Henson, J. M., and French, R. 1993. The polymerase chain reaction and plant disease diagnosis. Annu. Rev. Phytopathol. 31:81-109.

14. Jalali, B. L., and Chand, H. 1992. Chickpea wilt. Pages 420-444 in: Plant Diseases of International Importance. Vol. 1. Diseases of Cereals and Pulses. U. S. Singh, A. N. Mukhopadhayay, J. Kumar, and H. S. Chaube, eds. Prentice Hall, Englewood Cliffs, NJ.

15. Jiménez-Díaz, R. M., Alcalá-Jiménez, A. R., Hervás, A., and TraperoCasas, J. L. 1993. Pathogenic variability and hosts resistance in the Fusarium oxysporum f. sp. ciceris/Cicer arietinum pathosystem. Pages 87-94 in: Proc. 3rd Eur. Semin. Fusarium Mycotoxins, Taxonomy, Pathogenicity and Host Resistance. Hodowsla Ròslin Aklimatyazacja i Nasiennictwo. Plant Breeding and Acclimatization Institute, Radzikóv, Poland.

16. Jiménez-Gasco, M. M., Milgroom, M. G., and Jiménez-Díaz, R. M. 2002. Gene genealogies support Fusarium oxysporum f. sp. ciceris as a monophyletic group. Plant Pathol. 51:72-77.

17. Jiménez-Gasco, M. M., Pérez-Artés, E., and Jiménez-Díaz, R. M. 2001. Identification of pathogenic races $0,1 \mathrm{~B} / \mathrm{C}, 5$, and 6 of Fusarium oxysporum f. sp. ciceris with random amplified polymorphic DNA (RAPD). Eur. J. Plant Pathol. 107:237-248.

18. Kaiser, W. J., Klein, R. E., Larsen, R. C., and Wyatt, S. D. 1993. Chickpea wilt incited by pea streak carlavirus. Plant Dis. 77:922-926.

19. Kelly, A. G., Alcalá-Jiménez, A. R., Bainbridge, B. W., Heale, J. B., Pérez-Artés, E., and Jiménez-Díaz, R. M. 1994. Use of genetic fingerprinting and random amplified polymorphic DNA to characterize pathotypes of Fusarium oxysporum f. sp. ciceris infecting chickpea. Phytopathology 84:1293-1298.

20. Kelly, A. G., Bainbridge, B. W., Heale, J. B., Pérez-Artés, E., and Jiménez-Díaz, R. M. 1998. In planta-polymerase-chain-reaction detection of the wilt-inducing pathotype of Fusarium oxysporum f. sp. ciceris in chickpea (Cicer arietinum L.). Physiol. Mol. Plant Pathol. 52:397409.

21. Langin, T., Capy, P., and Daboussi, M. J. 1995. The transposable element impala, a fungal member of the Tc1-mariner superfamily. Mol. Gen. Genet. 246:19-28.

22. Manulis, S., Kogan, N., Reuven, M., and Ben Yephet, Y. 1994. Use of the RAPD technique for identification of Fusarium oxysporum f. sp. dianthi from carnation. Phytopathology 84:98-101.

23. Martin, R. R., James, D., and Levésque, C. A. 2000. Impacts of molecular diagnostic technologies on plant disease management. Annu. Rev. Phytopathol. 38:207-239.

24. McDermott, J. M., Brändle, U., Dutly, F., Haemmerli, U. A., Keller, S., Müller, K. E., and Wolfe, M. S. 1994. Genetic variation in powdery mildew of barley: Development of RAPD, SCAR and VNTR markers. Phytopathology 84:1316-1321.

25. Namiki, F., Shiomi, T., Kayamura, T., and Tsuge, T. 1994. Characterization of the formae speciales of Fusarium oxysporum causing wilts of cucurbits by DNA fingerprinting with nuclear repetitive DNA sequences. Appl. Environ. Microbiol. 60:2684-2691.

26. Nelson, P. E., Tousson, T. A., and Cook, R. J. 1981. Fusarium: Diseases, Biology and Taxonomy. The Pennsylvania University Press, University Park

27. Nogales-Moncada, A. M. 1997. Compatibilidad Vegetativa en Fusarium oxysporum f. sp. ciceris y Fusarium oxysporum f. sp. melonis, Agentes, Respectivamente de las Fusariosis Vasculares del Garbanzo y del Melón. Ph. D. Thesis. University of Córdoba, Córdoba, Spain.

28. Okuda, M., Ikeda, K., Namiki, F., Nishi, K., and Tsuge, T. 1998. Tfol: An Ac-like transposon from the plant pathogenic fungi Fusarium oxysporum. Mol. Gen. Genet. 258:599-607.

29. Paran, I., and Michelmore, R. W. 1993. Development of reliable PCR- 
based markers linked to downy mildew resistance genes in lettuce. Theor. Appl. Genet. 85:985-993.

30. Pérez-Artés, E., Roncero, M. I. G., and Jiménez-Díaz, R. M. 1995. Restriction fragment length polymorphism analysis of the mitochondrial DNA of Fusarium oxysporum f. sp. ciceris. J. Phytopathol. 143:105-109.

31. Raeder, U., and Broda, P. 1985. Rapid DNA preparation from filamentous fungi. Lett. Appl. Microbiol. 1:17-20.

32. Rieseberg, L. H. 1996. Homology among RAPD fragments in interspecific comparisons. Mol. Ecol. 5:99-105.

33. Sambrook, J., Fritsch, E. F., and Maniatis, T. 1989. Molecular Cloning: A Laboratory Manual, 2nd ed. Cold Spring Harbor Laboratory, Cold
Spring Harbor, NY.

34. Trapero-Casas, A., and Jiménez-Díaz, R. M. 1985. Fungal wilt and root rot diseases of chickpea in southern Spain. Phytopathology 75:11461151.

35. Ward, E. 1994. Use of polymerase chain reaction for identifying plant pathogens. Page 143-160 in: Ecology of Plant Pathogens. J. P. Blakeman and $\mathrm{B}$. Williamson, eds. CAB International, Oxon, UK.

36. Wiglesworth, M. D., Nesmith, W. C., Schardl, C. L., Li, D., and Siegel, M. R. 1994. Use of specific repetitive sequences in Peronospora tabacina for early detection of the tobacco blue mold pathogen. Phytopathology 84:425-430. 